\title{
GYÁRTÁS FOLYAMATKÉPESSÉGÉNEK VISSZAIGAZOLÁSA STATISZTIKAI MÓDSZEREKKEL
}

\author{
Nagy Krisztián \\ beszállitói minöségbiztositási mérnök, Robert Bosch Elektromos Szerszámgyártó Kft. \\ 3526 Miskolc, Robert Bosch Park 1, e-mail: krisztian.nagy@hu.bosch.com \\ Varga Gyula \\ egyetemi docens, Miskolci Egyetem, Gyártástudományi Intézet \\ 3515 Miskolc, Miskolc-Egyetemváros, e-mail: gyulavarga@uni-miskolc.hu
}

\begin{abstract}
Absztrakt
A gyártás tervezés során az egyik elsödleges cél a hibamentes folyamat elérése, ezzel biztositva a gyártott alkatrészek, termékek megfelelö minöségét és kedvezö gyártási költségét. A gyakorlatban elkövetett hibákat megemlítve a cikkben megtalálható a gyártás tervezés során szükséges lépések, annak érdekében, hogy a lehetö legkisebb hibaarányt el lehessen érni. Mindehhez statisztikai módszereken alapuló vizsgálatok szükségesek. A mérörendszer megfelelöségét alapul véve két példa kapcsán kerül bemutatásra a folyamatképességi vizsgálatok kivitelezése.
\end{abstract}

Kulcsszavak: minőség tervezés, folyamatképesség, statisztikai vizsgálatok

\begin{abstract}
At production planning, one of the main goals is to reach the failure-free process. Therefore, the quality of the parts, products will be stable on the best price level. We can see the necessary steps in the project phase to reach the best failure rate for the production and read some typical failures from the practice. All this we use different analysis with statistical methods. Two examples will be presented about capability studies when we presume the proper measuring system.
\end{abstract}

Keywords: quality planning, capability of the process, statistical examinations

\section{Bevezetés}

Napjainkban a cégek életének legnagyobb részét a piacon való versenyképesség javítása, fenntartása teszi ki. A folyamatos fejlesztések, a produktivitás javítása, az automatizálás elengedhetetlen ennek elérése érdekében. A modern technológia alkalmazása nem elegendő ahhoz, hogy a gyártási folyamat stabil legyen, ne keletkezzen hibás termék, valamint ne kerüljön ki a vevőhöz. Tehát a folyamatot szabályozni kell, ami a munkadarabok ismérveinek időszakos vizsgálataival, mérésével valósul meg. Fontos, hogy a folyamatba történő beavatkozás időben megtörténjen, mielőtt hibás termék keletkezne. Ezzel pedig a selejt költség szüntethető meg, amivel nem csak a vevői elégedettséget lehet megnövelni, hanem segít a versenyképes ár elérésében is. Ennek megvalósítása érdekében egy rendszert kell kidolgozni, a mérőeszköz megfelelő kiválasztásától kezdve a statisztikai folyamatszabályozásig (SPC). Alkalmazható 
kézi számítási eljárás mind a mérőrendszer, mind a gép- és folyamatképességi vizsgálatokhoz, de csak abban az esetben, ha normál eloszlásról van szó. A gyakorlat azt mutatja, hogy a mérőrendszer vizsgálata során eredményesen használható, de a különböző gyártási folyamatokat, termék paramétereket nem minden esetben lehet normál eloszlás alapján leírni. Ekkor az látható, hogy a haranggörbe valamelyik irányba megdől, és ha az nem kerül valamilyen módon korrigálásra, akkor a normál eloszlás hibás eredményt eredményez a görbe szélső értékeinél. Ebben az esetben olyan eloszlás függvényt kell választani, ami pontosabban leírja a folyamatot, a megadott mérési eredmények alapján. Ezért kiemelten fontos a statisztikai programok használata.

A mérőrendszer bemenetének (mérőeszköz, ember, alkatrész, környezet, módszer stb.) ingadozása a kimenet ingadozását eredményezi. A mérési adatokat elemezve lehet minősíteni a termékeket, a gyártási folyamatokat és arról való döntést, hogy pl. [1]:

- Megfelelö, vagy nem megfelelő a termék?

- A kívánt folyamatképesség el lett-e érve, vagy javítani kell a folyamaton?

Egy mérőrendszert alkalmazó ember a termékparaméterek függvényében négyféle döntést hozhat (1. ábra):

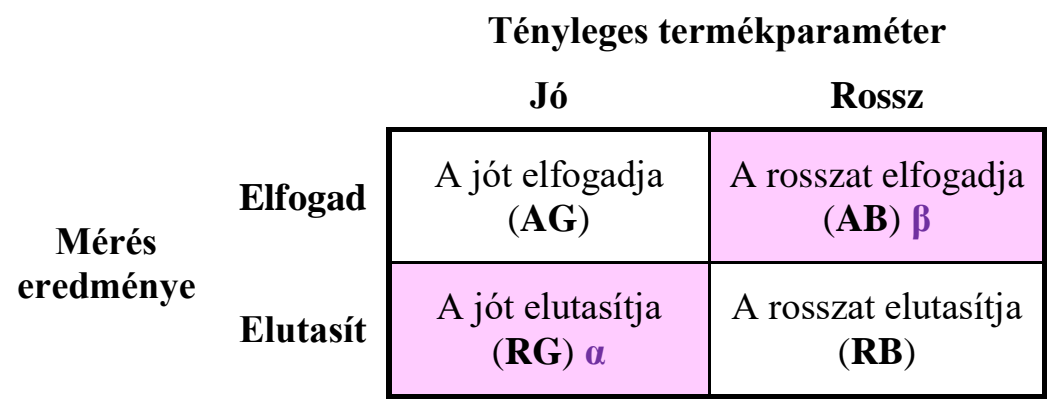

1. ábra. Döntéshozatali lehetöség a termékparaméterek függvényében [1]

A mérörendszer ingadozásának (szórásának) növekedésével a jó termék elutasítás és rossz termék elfogadás valószínüsége növekszik (1. ábra).

A fentiekkel összhangban a mérőrendszer elemzés célja [1]:

- Számszerüsíteni, mekkora a mérőrendszer által okozott ingadozás a termelési folyamat ingadozásához képest és az elfogadható-e számunkra?

- Mennyire lehet támaszkodni a mérési folyamatból származó adatokra, amikor egy gyártási folyamat jellemzéséről van szó, azaz mennyire ,jók" az adatok olyan értelemben, hogy jellemzően a folyamat ingadozását tükrözik-e nem pedig a mérés bizonytalanságát, amely a leolvasott értékekben jelenik meg.

A 2. ábra a gyártás folyamatképességének visszaigazolására szolgál. Egy folyamatábrát tartalmaz, mely lépésről-lépésre bemutatja, hogy ehhez milyen vizsgálatok elvégzése szükséges. A vizsgálatokat két fő részre oszthatjuk, az egyik a mérőrendszer felépítése és az ahhoz kapcsolódó ellenőrzések, míg a második szakaszban a gyártási folyamatot érintő vizsgálatok szerepelnek. A mérőrendszer elemzésről (MSA) részletes információt tartalmaz az MSA Referencia kézikönyv [2]. Az ellenőrzés első lépése a 
megfelelő mérőeszköz kiválasztása, majd a mérőeszköz pontosságának ellenőrzése $\left(\mathrm{C}_{\mathrm{g}}, \mathrm{C}_{\mathrm{gk}}\right)$, ezt követően a mérési módszer ismételhetőségének és reprodukálhatóságának vizsgálatára (GRR) következik.

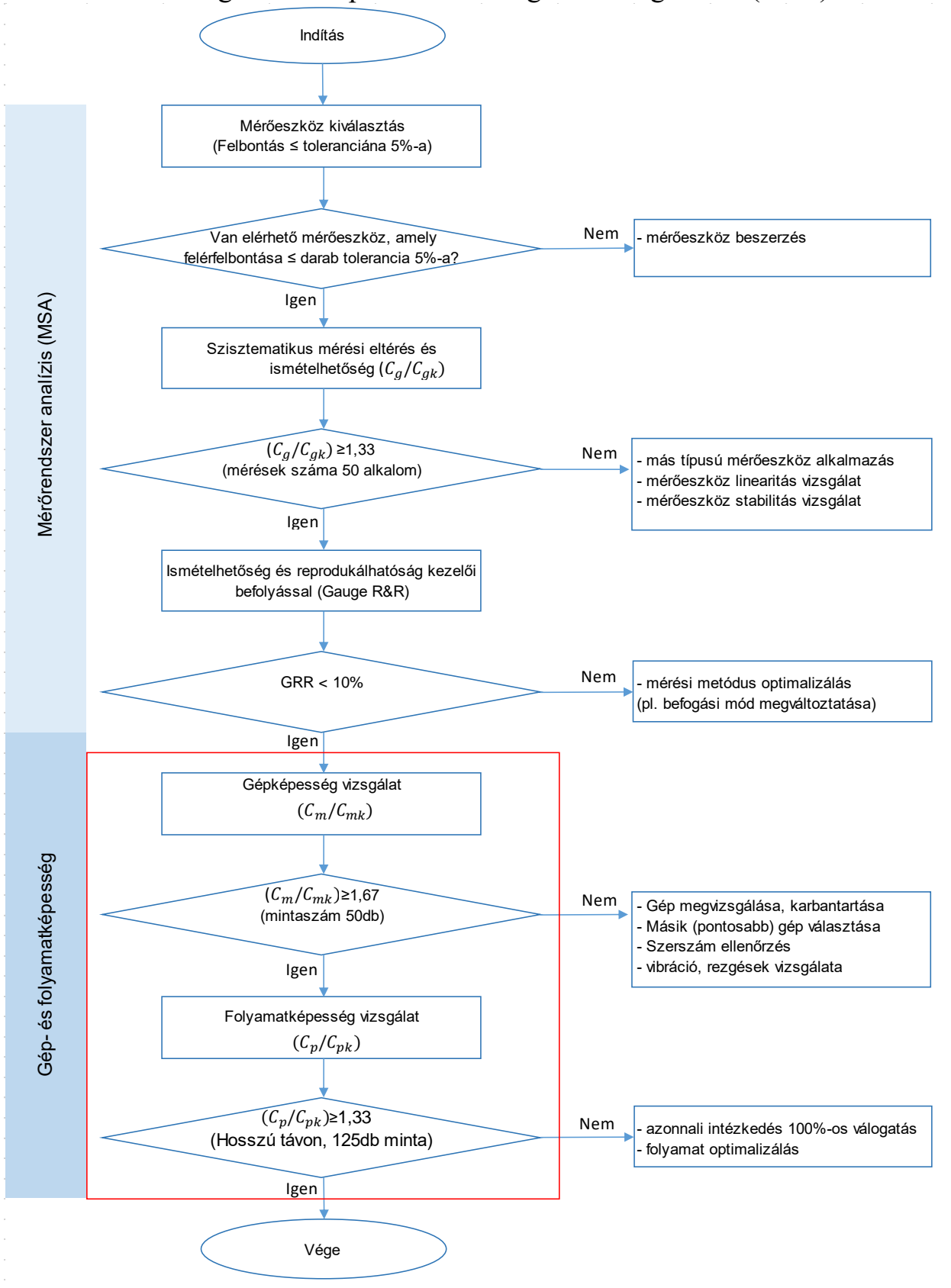

2. ábra. Folyamatábra a mérörendszer és a folyamatképességi vizsgálatok kialakitására 
Nagy, K., Varga, Gy.

Gyártás folyamatképességének visszaigazolása statisztikai módszerekkel

Csak akkor mondhatjuk ki a mérőrendszerünk megfelelőségét, ha mindkét vizsgálat eredménye megfelelő. Ezzel megbizonyosodtunk a mérőeszköz és a mérési módszer helyességéről, amivel vizsgálhatjuk elöször a gyártó berendezés pontosságát, majd a gyártási folyamat stabilitását [3-4].

Jelen vizsgálatnál feltételezzük, hogy a mérőrendszer megfelelően lett kiépítve. A legtöbbször elkövetett hiba, hogy nem kerül sor a mérörendszer visszaigazolására, de így a kapott eredmények sem lesznek megbízhatóak. Sokszor csak a hibaanalízis során derül ki, hogy a mérőeszköz nem megfelelő vagy a mérési módszer nem ismételhető [5-7].

\section{Gépképesség vizsgálatok}

A gépképesség vizsgálat elvégzése a következő példán keresztül kerül bemutatása. Látható, hogy nem elegendő a mérési adatok szoftverbe való importálása és a kiértékelés elvégzése, mert nem elfogadható eredmény során nincs információnk a mért darabokról, így a hibaanalízis nem végezhető el. Tehát a példa rámutat arra, hogy milyen nagy szerepe van a szükséges adatok mintákhoz rendelésének.

A kiindulási adatokat és a kézi számítás elvégéséhez szükséges képleteket a 3. ábra tartalmazza. A számítások alapján a gépképesség nem éri el a $C_{m} ; C_{m k}>1,66$-os határértéket, így a folyamat nem elfogadható.

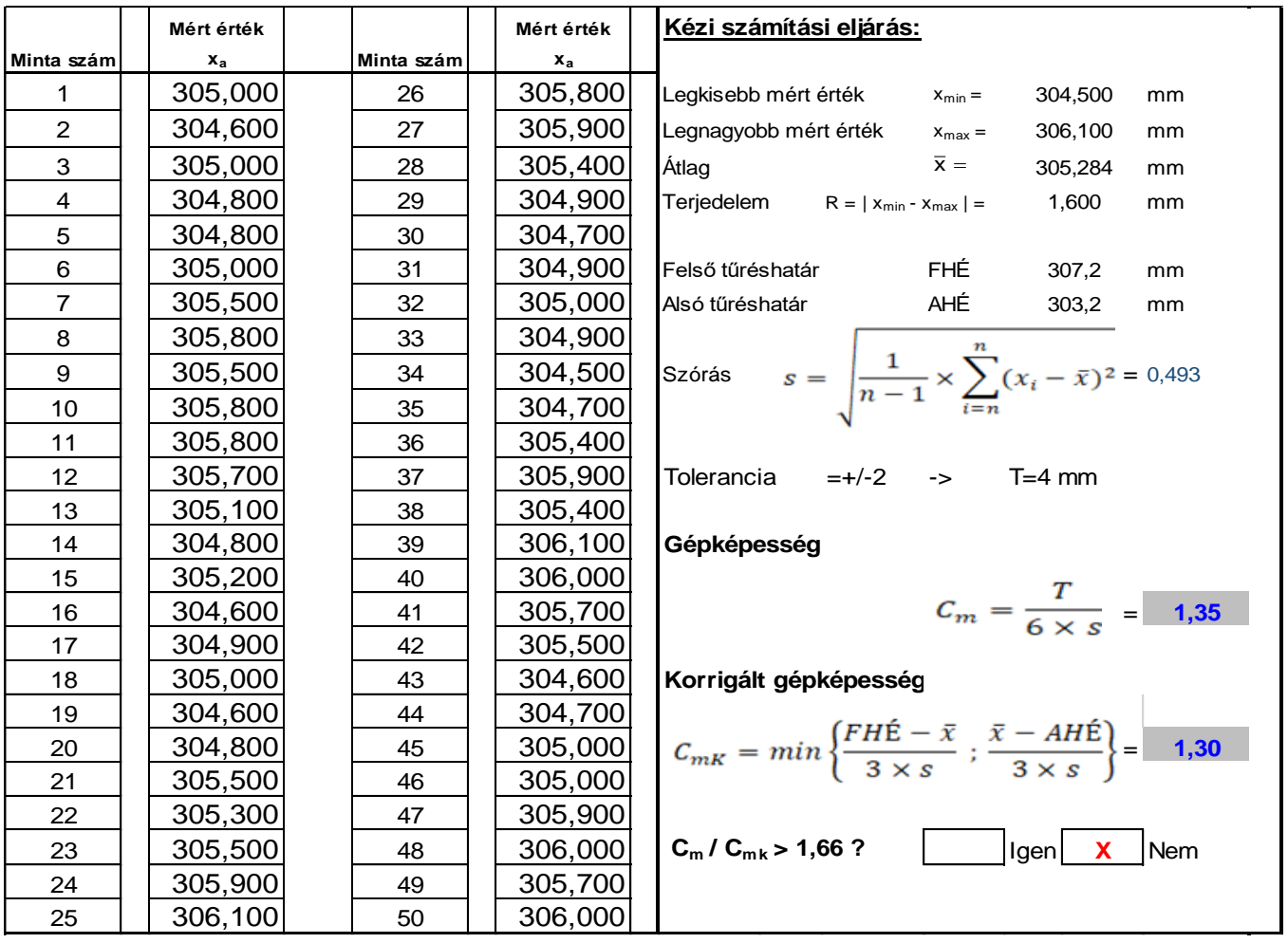

3. ábra. Gépképesség vizsgálat kézi számitás alapján 
Az adatokat a $Q$-das statisztikai program erre vonatkozó qs-STAT moduljába illesztve a számítás másképpen történik. Az adatok eloszlását figyelembe véve, a beállított stratégia alapján, a szoftver automatikusan kiválasztja az optimális eloszlás modellt. A szoftveres kiértékelés eredménye a 4. ábrán látható.

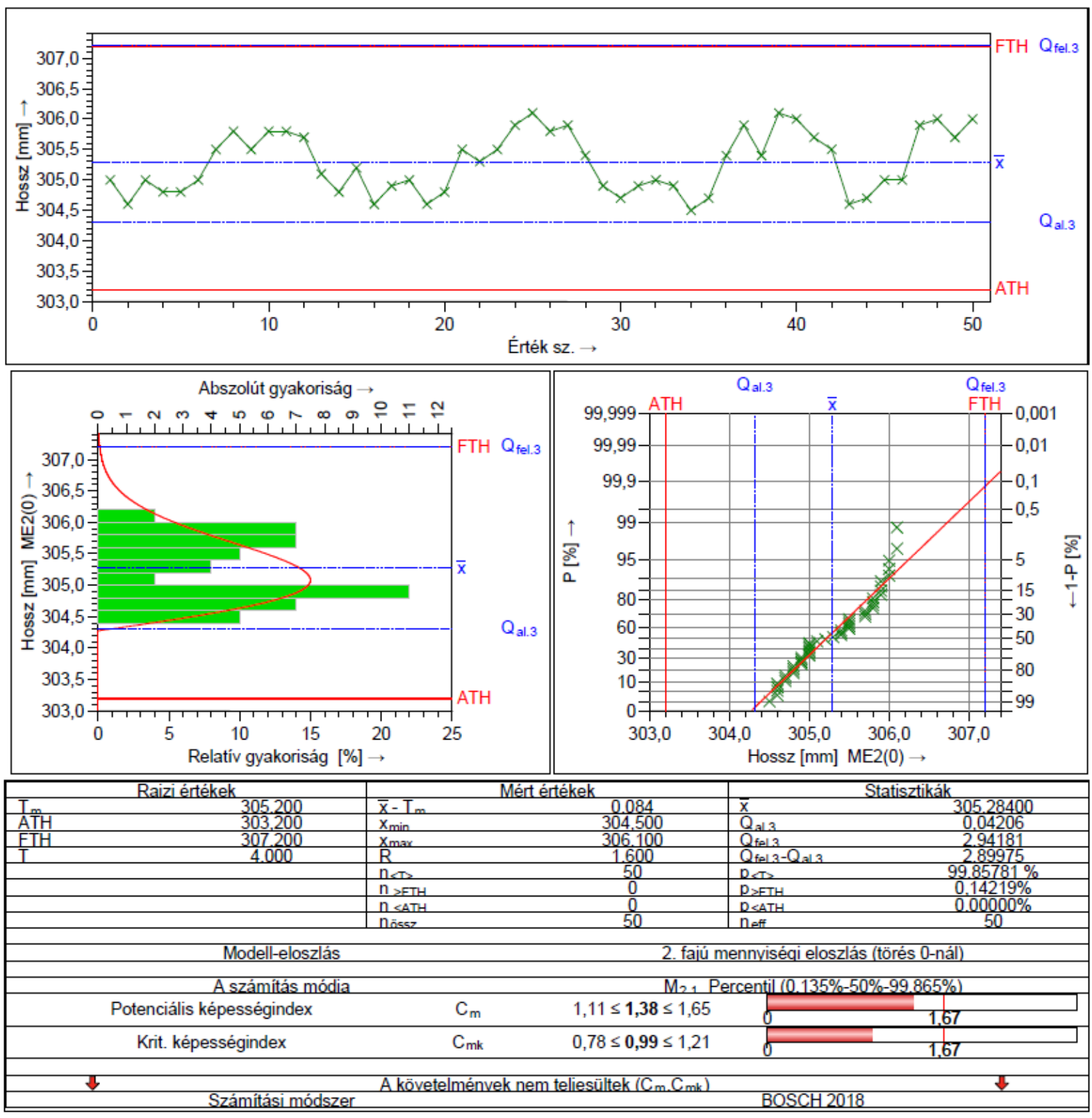

4. ábra. Gépképesség vizsgálat Q-das szoftverrel 
Az eredmény eltér a kézi számításhoz képest, mivel 2. fajú mennyiségi eloszlás modell szerint történtek a számítások, de az eredmény ebben az esetben sem elfogadható.

Mi a teendö ebben az esetben?

Hibaanalízist kell indítani és megvizsgálni minden olyan tényezőt, amely hatással van vagy lehet a darab legyártott méretére. Ilyen tényezők lehetnek, pl.: az ember, anyag, gép, folyamat, módszer és környezet. Amennyiben sikerül megállapítani olyan tényezőket, amelyek negatív hatással vannak a folyamatra, akkor azok kiküszöbölésére javító intézkedéseket kell hozni. Majd újabb mintagyártás szükséges az akciók sikerességének visszaigazolására, valamint a gépképesség újbóli elemzéséhez.

A 4. ábrán látható hisztogramon megfigyelhetö, hogy két csúccsal rendelkezik, ami abból adódik, hogy a gyártó berendezés két fészekszámmal rendelkezik, így egy ciklus alatt egyszerre két alkatrész gyártása folyik. Ez csak a hiba analízist követően került megállapításra, hogy nem megfelelően történt a minták kivétele és jelölése. Amennyiben a fenti 50 darab mérési eredményt szétbontjuk 25-25 darabos csoportban a fészekszámok alapján és külön vizsgáljuk, akkor normál eloszlást fogunk látni és folyamatképes eredményt kapunk. Ez látható az 5. ábrán.

A 25 darabos mintaszám elfogadható, de ebben az esetben a $C_{m} ; C_{m k}>2$ kell, hogy teljesüljön. A példa rávilágított arra, hogy nagy hangsúlyt kell fektetni arra, hogy a lehetö legtöbb információ kigyüjtésre kerüljön a mintagyártás során és azok megfelelően dokumentálva legyenek, úgy, hogy később a mintákhoz hozzárendelhetők legyenek. Tehát minél több adat áll rendelkezésre, annál könnyebb megérteni a jelenséget a kiértékelést követő nem elfogadható eredmény kapcsán.

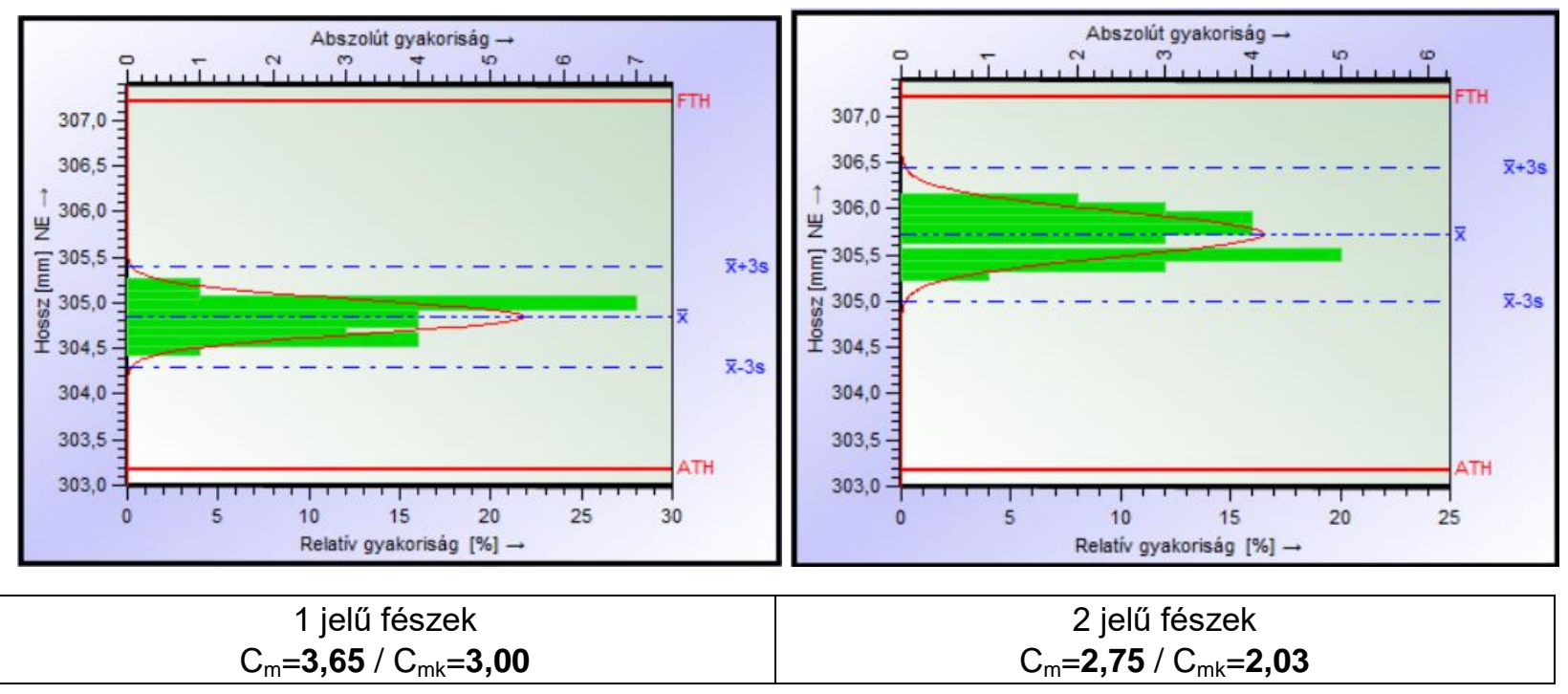

5. ábra. Az adathalmaz fészekszám szerinti szétbontását követö gépképesség vizsgálat

\section{Folyamatképesség vizsgálatok}

A gépképesség visszaigazolását követően kezdhető meg a folyamatképesség vizsgálata, amely hosszabb folyamat és a minta sorozatok kivétele is más szempont alapján történik. Míg a gépképesség során 
kizártunk minden befolyásoló tényezőt, most ennek az ellenkezőjét kell csinálni. Úgy kell kivenni a mintákat, hogy a folyamatra kiható tényezőket figyelembe vegyük és ezt az információt hozzárendelni a mintákhoz. Ilyen befolyásoló tényezők a különböző kezelő személyek, müszakok, alapanyag csere, folyamat újraindítás, szerszámcsere, karbantartás és minden olyan változás, amely kihatással lehet a gyártott termékre. Tehát ember, anyag, gép, folyamat, módszer és környezetbe tartozó zavaró hatások. Az elterjedt minta mennyiség 5 darab az egyes mintavételek során és minimum 125 darab szükséges a vizsgálat elvégzéséhez. A folyamatra ható dolgok alapján belátható, hogy a mintagyújtés hosszú távon történik. A korábban leírtak alapján ezeket a vizsgálatokat a lehető leghamarabb érdemes elvégezni, hogy következtetni tudjunk a szériagyártás megfelelőségére és stabilitására. Ezért a folyamatképesség vizsgálatot két részre osztjuk. Az egyik a rövid távú vizsgálat, ami során egy minta széria is elegendő lehet, amiben beletesszük azokat a változásokat, ami az adott időszakban lehetséges, és abból vesszük ki a mintákat. Ez a gyakorlatban egy vagy maximum két müszakos gyártás. Ilyen esetben a definiált cél a $C_{p(s t)} ; C_{p k(s t)} \geq 1,67$.

Az 'ST' jelölés az angol „Short Term” rövidítéséből származik, ami a „rövidtáv”-ot jelöli. Ez alapján a folyamat jóváhagyható még szériagyártás megkezdése előtt. Hosszú távon törekedni kell arra, hogy minden gyártási szériából kellő számú sorozat legyen kivéve több szérián keresztül, ez lehet 1 vagy 3 hónap is, a gyártási mennyiség nagysága és gyakorisága alapján. Ekkor már elegendő a $C_{p} ; C_{p k} \geq 1,33$ teljesítése. A számítási metódus megegyezik a gépképességnél alkalmazott formulával.

Az $n$ darab $x_{i}$ mérési eredménybő kiszámoljuk az $\bar{x}$ teljes átlagot és $s_{\text {teljes }}$ szórást:

$$
\bar{x}=\frac{1}{n} \cdot \sum_{i=1}^{n} x_{i}
$$

$$
s_{\text {teljes }}=\sqrt{\frac{1}{n-1} \cdot \sum_{i=1}^{n}\left(x_{i}-\bar{x}\right)^{2}}
$$

Ezekből pedig a folyamatképességi mutatószámok:

$$
C_{p}=\frac{T}{6 \cdot s_{\text {teljes }}}
$$

$$
C_{p k}=\min \left\{\frac{F H E ́}{3 \cdot s_{\text {teljes }}} ; \frac{\bar{x}-A H E ́}{3 \cdot s_{\text {teljes }}}\right\}
$$

ahol:

$T:$ - türésmező

$$
T=(F H E ́-A H E ́)
$$

FHÉ: - felső határérték

AHÉ: - alsó határérték

A 6. ábra megmutatja, hogy statisztikai szoftver alkalmazásával kapunk megfelelő képet a folyamatunkról. A kézi számítási eljárás képleteivel könnyen készíthetünk egy Excel táblázatot, amivel az adatok beillesztését követően az eredményt automatikusan megkapjuk, de így minden adathalmaz esetében a normál eloszlás lesz alkalmazva. A kiindulási adatokat a 1. táblázat tartalmazza.

A vizsgálandó méret nem korlátos és a 6 . ábrán látható eloszlást tekintve nem tünik rossz megoldásnak a normál eloszlási modell alkalmazása. Viszont a kapott értékek alapján a folyamat nem hagyható jóvá. 
Nagy, K., Varga, Gy.

Gyártás folyamatképességének visszaigazolása statisztikai módszerekkel

Amennyiben a mért értékeket a $Q$-das szoftverbe illesztjük be, akkor a beállított stratégia és a mért adatok eloszlását alapul véve, a logaritmikus normál eloszlás modellt választja ki és alkalmazza a szoftver. Ez látható a 7 . ábrán. Így a $C_{p} ; C_{p k}>1,33$ feltétel teljesül.

1.táblázat. Kiinduló adathalmaz

\begin{tabular}{|c|r|l|}
\hline Rajzi érték & 2,50 & $\mathrm{~mm}$ \\
\hline Türés & 0,15 & $\mathrm{~mm}$ \\
\hline
\end{tabular}

\begin{tabular}{|l|l|l|}
\hline ATH & 2,40 & $\mathrm{~mm}$ \\
\hline FTH & 2,55 & $\mathrm{~mm}$ \\
\hline
\end{tabular}

\begin{tabular}{|r|r|r|r|r|r|r|r|r|r|r|r|}
\hline 1 & 2,44 & 2,46 & 2,48 & 2,49 & 2,44 & 2,47 & 2,48 & 2,5 & 2,46 & 2,51 & 2,45 \\
\hline 2 & 2,44 & 2,46 & 2,48 & 2,49 & 2,44 & 2,47 & 2,48 & 2,5 & 2,47 & 2,52 & 2,45 \\
\hline 3 & 2,44 & 2,47 & 2,48 & 2,49 & 2,45 & 2,47 & 2,48 & 2,51 & 2,48 & 2,45 & 2,46 \\
\hline 4 & 2,45 & 2,47 & 2,48 & 2,49 & 2,45 & 2,47 & 2,48 & 2,46 & 2,46 & 2,45 & 2,46 \\
\hline 5 & 2,45 & 2,47 & 2,48 & 2,5 & 2,45 & 2,47 & 2,48 & 2,48 & 2,46 & 2,45 & 2,46 \\
\hline 6 & 2,45 & 2,47 & 2,48 & 2,5 & 2,45 & 2,47 & 2,48 & 2,49 & 2,48 & 2,45 & 2,45 \\
\hline 7 & 2,45 & 2,47 & 2,48 & 2,5 & 2,45 & 2,47 & 2,48 & 2,47 & 2,49 & 2,46 & 2,46 \\
\hline 8 & 2,45 & 2,47 & 2,48 & 2,51 & 2,46 & 2,47 & 2,48 & 2,47 & 2,47 & 2,46 & 2,46 \\
\hline 9 & 2,46 & 2,47 & 2,48 & 2,51 & 2,46 & 2,47 & 2,49 & 2,48 & 2,46 & 2,46 & 2,47 \\
\hline 10 & 2,46 & 2,47 & 2,48 & 2,51 & 2,46 & 2,48 & 2,49 & 2,5 & 2,47 & 2,46 & 2,47 \\
\hline 11 & 2,46 & 2,47 & 2,48 & 2,44 & 2,46 & 2,48 & 2,49 & 2,46 & 2,48 & 2,45 & 2,47 \\
\hline 12 & 2,46 & 2,47 & 2,48 & 2,46 & 2,46 & 2,48 & 2,49 & 2,49 & 2,49 & 2,45 & 2,45 \\
\hline 13 & 2,46 & 2,47 & 2,47 & 2,47 & 2,42 & 2,43 & 2,43 & 2,45 & 2,45 & 2,45 & 2,46 \\
\hline
\end{tabular}

Normál eloszlás esetében a következő eredményt kapjuk:

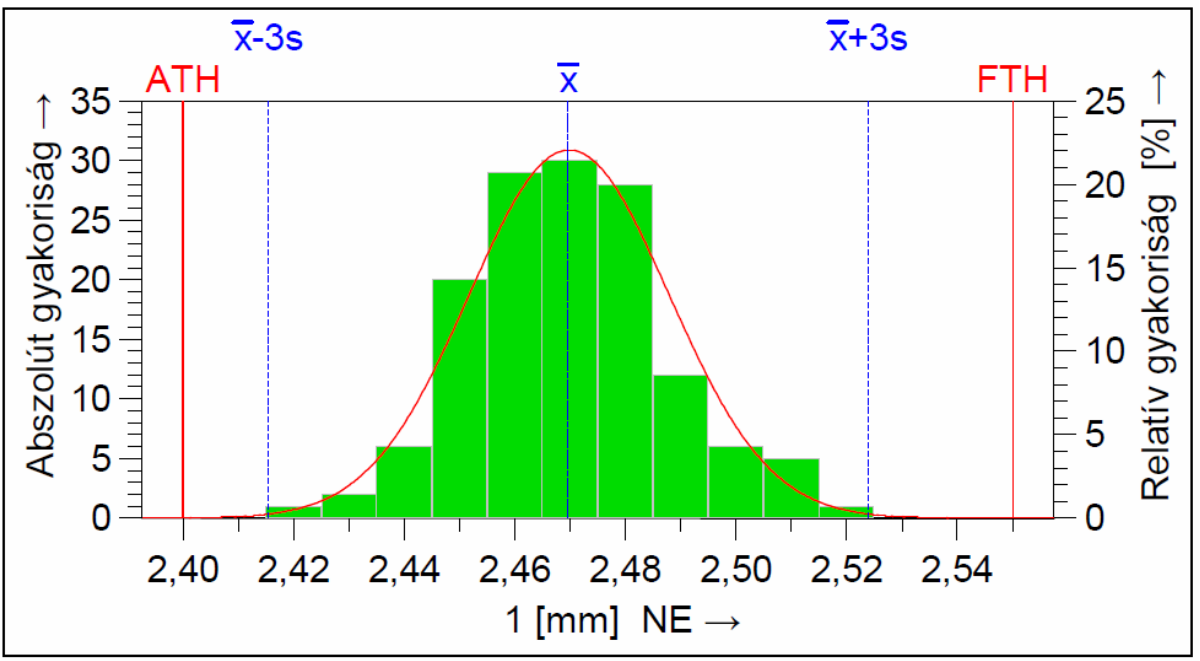

\begin{tabular}{|c|c|ccc|}
\hline Potenciális képességindex & $\mathrm{C}_{\mathrm{p}}$ & & $1,22 \leq 1,38 \leq 1,54$ & 0 \\
\cline { 1 - 2 } \cline { 5 - 6 } Kritikus képességindex & $\mathrm{C}_{\mathrm{pk}}$ & & $1,12 \leq 1,28 \leq 1,44$ & 0 \\
\hline
\end{tabular}

6. ábra. Normál eloszlás függvény szerinti kiértékelés 


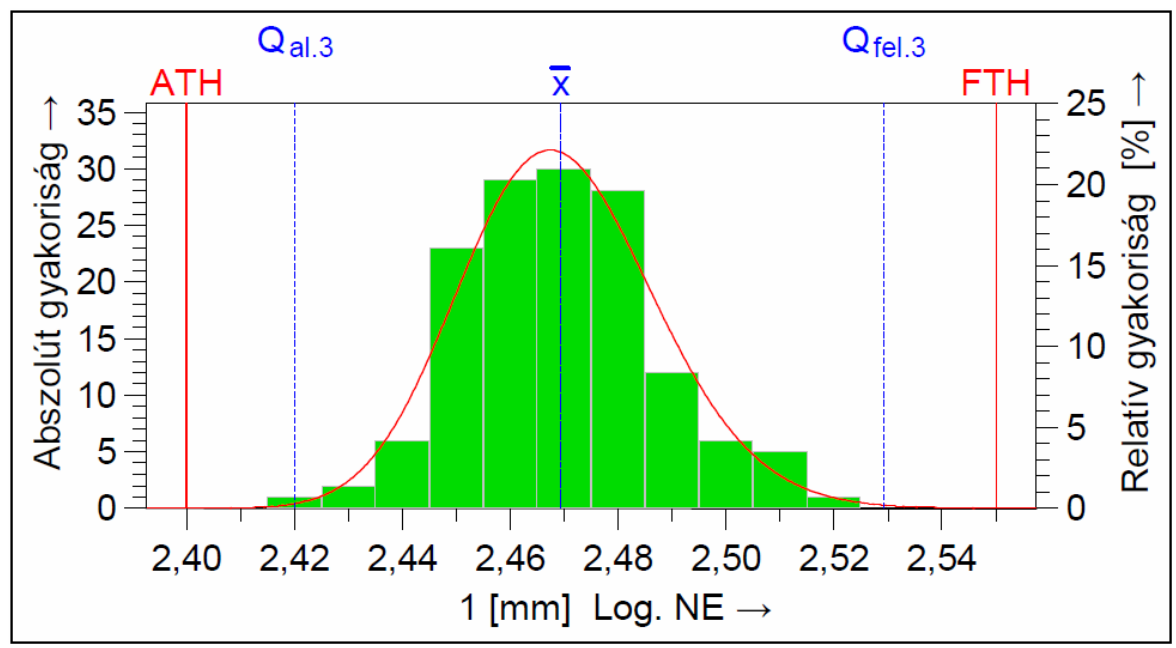

\begin{tabular}{|c|c|c|c|}
\hline Potenciális képességindex & $\mathrm{C}_{\mathrm{p}}$ & 1,22 & (1) \\
\hline & & & 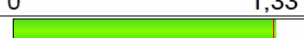 \\
\hline Kritikus képességindex & $\mathrm{C}_{\mathrm{pk}}$ & $1,18 \leq 1,34 \leq 1,51$ & 1,33 \\
\hline
\end{tabular}

7. ábra. Logaritmikus normál eloszlás függvény szerinti kiértékelés

Ez még a szerencsésebb eset, hogy a kézi számítás során jött ki a nem elfogadható eredmény. Amennyiben ez fordítva történik és az adatok nincsenek kiértékelve szoftveresen, akkor könnyen előfordul, hogy egy nem folyamatképes gyártás jóváhagyása történik meg, aminek a hátterében az áll, hogy nem az optimális függvény volt alkalmazva. Ez a hiba a gyakorlatban sokszor elöfordul. Ha a kapott eredmény a teljesítendö határértéket $(1,33)$ éppen, hogy csak túllépi, akkor érdemes az 'n' mintaszámot növelni és újból kiértékelni az adatokat.

\section{4. Összefoglalás}

A mérőrendszer és a képességvizsgálatok elvégzése kiemelten fontos a projekt kezdeti szakaszában, elvégzendő olyan hamar, amilyen hamar lehetséges. Ha a hiba a szériagyártás során derül ki, akkor annak kijavítása sokkal több erőforrást és költséget igényel. Gyakori hiba, hogy a cégek többsége nem fordít kellö hangsúlyt a mérőrendszerre és az alapvető elemzések hiányoznak. Ebben az esetben nem tudjuk biztosan mondani, hogy a kiválasztott mérőeszköz megfelelő a munkadarab mérendő méretéhez vagy az alkalmazott mérési módszerrel ismételhető mérési értékeket kapunk. Emellett belátható, hogy statisztikai szoftver alkalmazása nélkül nem biztos, hogy a gyártási folyamatot helyesen leíró, megfelelö eloszlás függvény kerül alkalmazásra. 
Nagy, K., Varga, Gy.

Gyártás folyamatképességének visszaigazolása statisztikai módszerekkel

\section{Köszönetnyilvánítás}

A cikkben ismertetett kutató munka az EFOP-3.6.1-16-2016-00011 jelü „Fiatalodó és Megújuló Egyetem - Innovatív Tudásváros - a Miskolci Egyetem intelligens szakosodást szolgáló intézményi fejlesztése" projekt részeként - a Széchenyi 2020 keretében - az Európai Unió támogatásával, az Európai Szociális Alap társfinanszírozásával valósul meg.

\section{Irodalom}

[1] MSA - mérőrendszer elemzés, https://www.poligont.hu/files/MSA-elemzespoligont.pdf?type=INFOM (megtekintés dátuma: 2019.05.13.)

[2] N.N.: Mérési rendszerek elemzése, MSA, Referencia kézikönyv, Negyedik kiadás, 2010. június, Chrysler Group LLC, Ford Motor Company, General Motors Corporation, ISBN: 978-1-60534211-5

[3] Quality Management in the Bosch Group - Booklet No. 9 - Machine and Process Capability (5th edition) (megtekintés dátuma: 05.11.2019)

[4] Quality Management in the Bosch Group - Booklet No. 10 - Capability of Measurement and Test Processes (megtekintés dátuma: 02.12.2019)

[5] https://statisztikaegyszeruen.blog.hu/2019/04/22/elso_az_egyenlok_kozott_a_ standard_normal_eloszlas (megtekintés dátuma: 2020.01.13.)

[6] Képesség vizsgálatok - Folyamatképesség II - Cp, Cpk https://www.haris-engineering.com/single-post/2016/3/16/Folyamatk\%C3\%A9pess\%C3\%A9g-IICp-Cpk (megtekintés dátuma: 2020.01.06.)

[7] http://www.qualitysupport.hu/images/Metrolgia.pdf (megtekintés dátuma: 2020.01.06.) 